\title{
Kiegészítő megjegyzések László Csaba A magánnyugdíjpénztári rendszer „elszámolása” címü tanulmányához
}

Pótolhatatlanul forrásértékủ, tananyagként is használható, terjedelmes tanulmányt tett közzé e folyóirat hasábjain László Csaba, a Budapesti Corvinus Egyetem címzetes egyetemi tanára, aki az 1998-as nyugdíjreformot megelőzően pénzügyminisztériumi helyettes államtitkárként a reform előkészítésének egyik fő felelőse volt. A cikk címében szóviccet rejtett el, hiszen az írás fő mondanivalója az, hogy a reform II. pillérének, a kötelezö magánnyugdíjpénztári rendszernek a felszámolása szoros összefüggésben állt azzal, ahogyan az Európai Unió különböző időpontokban, különféle módon rendelte elszámolni a II. pillér, a kötelező magánnyugdíjpénztári rendszer bevezetése nyomán keletkezett költségvetési hiányt.

A cikk végkövetkeztetésével azonban nem teljesen vagy nem úgy értek egyet, ahogy a szerző gondolta. A 895. oldal tetején ezt olvashatjuk: „A magyar kötelező magánnyugdijrendszer felszámolását teljesen egyértelmüen az EU-nak ez a hozzáállása váltotta ki." Egy korábbi helyen a szerző még egy bizalmas közlésen alapuló személyes információra is utal: a magyar kormány 2010 nyarán megüzente Brüszszelnek, hogy amennyiben az EU ragaszkodik ahhoz, hogy a kötelező magánnyugdíjrendszer miatt évente keletkező hiányt a soron következő, 2011-es költségvetésben beszámítsák a deficitbe, annak „a második pillér felszámolása lehet a következménye" (873. o. és a 9. lábjegyzet). Végeredményben a cikk gondolatmenete oda fut ki, hogy a Bizottságnak bölcsebben kellett volna eljárnia a maastrichti kritériumok számonkérése során, és el kellett volna fogadnia azt az érvelést, hogy a nyugdíjreform miatti deficitet másképpen kell kezelni ebből a szempontból, mint más deficitgeneráló tételeket, s ha ez így lett volna, akkor még mai is müködne a kötelező magánnyugdíjpénztári rendszer Magyarországon.

De mit jelent a fentebb idézett mondatban az, hogy „ez a hozzáállása”? Tulajdonképpen két, egymástól független, de azért mégis összefüggő dolgot, amelyek közül A) az első a Bizottságra (mint politikai testületre); B) a második az Eurostatra (mint szakmai apparátusra) vonatkozott, az első a folyó évi hiány (flow) elszámolását, a második a II. pillérben felhalmozott vagyon (stock) elszámolását érintette.

* Közgazdasági Szemle, 65. évf. 9. sz. 861-902. o.

A kézirat első változata 2018. október 9-én érkezett szerkesztőségünkbe.

DOI: http://dx.doi.org/10.18414/KSZ.2018.11.1187 
A) A szerző szerint hiba volt, hogy a Bizottság 2011-re vonatkozóan már nem volt hajlandó a konvergenciafeltételek számítása során eltekinteni a II. pillér miatt évente keletkező 1,4 százaléknyi GDP-arányos hiánytól, miként azt Magyarország és több más hasonló helyzetü ország esetében tette csökkenő mértékben 2005 és 2010 között.

B) Másfelől, László Csaba arra utalt, hogy amikor Orbán Viktor döntött a II. pillér megszüntetéséről, akkor ő és beosztott munkatársai az Eurostat pillanatnyi elszámolási rendjét vették figyelembe, amelynek logikája szerint a kötelező magánnyugdíjpénztár államosításával keletkező bevétel - több mint 3000 milliárd forint, a GDP több mint 10 százaléka - 2011-re egy összegben elszámolható lesz. Ezzel a Bajnaikormánytól örökölt 2010-es nagymértékű (-4,5 százalékos) deficithez képest 2011re számottevő költségvetési többlet keletkezik (+4,3 százalék), aminek nyomán az ország kikerül a túlzottdeficit-eljárás alól, és feltehetően javul az államadósság besorolása is. Igaz, hogy a 2010-es nemzeti számlák európai rendszere (ESA2010) világosan elöírta, hogy az államháztartás minden bevételét és minden kiadását abban az évben kell elszámolni, amikor a mögöttes reálgazdasági folyamatok végbemennek, de egy korábbi, kompromisszumos politikai döntés alapján az Eurostat 2010-ben és 2011-ben még nem alkalmazta az ESA2010 szabályait. Ha tehát az ESA2010-et már 2011-ben is alkalmazta volna az Eurostat, akkor a II. pillér de facto felszámolásának semmi értelme sem lett volna, ergo nem is csinálták volna meg. ${ }^{1}$ Az EU a hibás: ez László Csaba cikkének végső üzenete.

Nem tudjuk, és talán sohasem fogjuk megtudni, hogy a részleteket illetően mit gondolt a miniszterelnök, amikor megfogadta azok tanácsát, akik a magánnyugdíjpénztári rendszer felszámolását javasolták - már közvetlenül a 2010-es választások előtt is, és utána is. ${ }^{2}$ Másfelől nézve viszont nagyon is valószínü, hogy akkor is felszámolták volna a kötelező magánnyugdíjpénztári rendszert, ha a magyar kormány biztosan tudta volna, hogy ezzel a „huszáros” csellel a 2011-es költségvetés egyenlegét érdemben nem lehet kozmetikázni, mert - az eredményszemléletü elszámolás logikája szerint - már az első pillanattól kezdve 35 évre elosztva számolták volna el a pénzforgalmi értelemben 2011-ben visszakerült 3000 milliárd forintot. Az ugyanis, hogy a 3000 milliárd forintnyi felhalmozott nyugdíjvagyon az államháztartástól független pénztárakból a kormányhoz került, nem elszámolási kérdés, itt valódi tulajdonosváltás történt a vagyont illetően.

Az egy másik kérdés, hogy a folyó hiány elszámolása szempontjából [fentebb: $A$ ) pont] elvileg melyik a jobb statisztikai megoldás. Az, amit 2005-2010 között alkalmazott a Bizottság, vagy az a 2011-től alkalmazott megközelítés, amely a túlzottdeficiteljárás szempontjából minden kozmetikázás nélkül ugyanazzal a hiányértékkel számol, mint amely az Eurostat adatbázisában szerepel. Szerintem egyértelmü - és ezt

\footnotetext{
${ }^{1} \mathrm{Az}$ egy fontos, de még feltárásra váró ténykérdés, hogy volt-e olyan KSH-szakértő, aki idejekorán szólt volna, hogy ami késik, nem múlik: egy-két év múlva mindenképpen be fogják vezetni az ESA2010-et, és akkor visszamenőlegesen is át fogják számolni a 2010-2013 közötti adatokat. Ugyanis pontosan ez történt 2014 októberében.

${ }^{2}$ Lásd például Németh [2009] cikkét a jelen folyóirat hasábjain.
} 
2006 táján is sokakkal szemben képviseltem (például kiváló gazdaságpolitikai szakemberekkel, Antal Lászlóval vagy Oblath Gáborral folytatott szakmai vitákon) -, hogy semmi értelme nincs a nyugdíjreform kiadásait (vagy bármely más kiadási tételt) nem beszámítani a deficitbe.

A deficit ugyanis nem exogén változó, az egy kivonás végeredménye: Deficit $=$ Bevételek - Kiadások. Makroökonómiai értelemben semmilyen deficitet - a külkereskedelmit vagy a fizetési mérleg deficitjét - sem lehetséges egy vagy több megnevezett kiadási tételnek betudni. Ugyanúgy nincs értelme azt mondani, hogy a költségvetés deficitje a kötelező magánnyugdijpénztár miatt volt, mint azt mondani, hogy a NATO-tagság vagy a nyugdíjak indexálása miatt. Minden kiadási tétel keresletet generál, minden hitelfelvétel után kamatot kell fizetni - makroszemléletben nézve teljesen közömbös, hogy értelmes vagy értelmetlen a kiadási cél. Ebböl következően a Bizottság (és az Eurostat) mai eljárása - szerintem - tökéletesen rendben van. Ha a statisztikusok minősíthetnék a kiadási célokat (ez hasznos, ez nagyon hasznos, ez nagyon-nagyon hasznos), akkor végül a politikusok akarata, illetve a politikusok alkujának végeredménye érvényesülne. Ez pedig nagy baj lenne. Tehát valójában nincs szükség az „elszámolási gyakorlat felülvizsgálatára” - mint ahogyan azt a szerzö a cikk végén leszögezi (897. o.).

László Csaba cikkének gondolatmenetét továbbvíve, azt is mondhatjuk, hogy mi, a nyugdíjreform kidolgozói is hibát követtünk el. ${ }^{3}$ Elfogadtuk a tankönyvekben szokásos ceteris paribus megközelítést, vagyis azt, hogy minden más változástól eltekintve, az 1998-tól érvényes új nyugdíjrendszerben a kötelező magánnyugdíjpénztárba befizetésre kerülő (és lassú ütemben a GDP-hez képest is növekedő) járulékmennyiség „hiányozhat" a központi költségvetésből. Ebben is volt persze logika. Minden költségvetés úgy készül, hogy a kiadások és a bevételek túlnyomó része múltbeli döntések által meghatározott, s amikor egy új kiadási (vagy az adott esetben bevételcsökkentő) tétel bevezetéséről döntünk, akkor van értelme a ceteris paribus megközelítésnek. Ha megszületik a döntés erről az új tételröl, akkor - minden egyebet változatlannak tekintve - ez és ez lesz a döntés hatása az egyenlegre. Ám rögtön meg is nyugtattuk magunkat, hogy a II. pillér megjelenése miatt nem lesz szükség több külföldi hitelfelvételre, mert pontosan ugyanebben a mértékben a kötelező rendszerhez tartozó magánnyugdíjpénztárak államkötvénybe fogják fektetni a hozzájuk átcsoportosuló járulékokat, és ráadásul a kötvényekért kifizetendő kamat is az országon belül marad. Akkor még messze volt az EU-csatlakozás, így emiatt nem is fájt a fejünk.

Ám a végeredmény mégiscsak az lett, hogy az államháztartás explicit adóssága az évi 1,0-1,5 százalékos többlethiány miatt évről évre nőtt. Márpedig azzal már 1997ben is tökéletesen tisztában voltunk mindannyian a döntéshozók közül, hogy az egész nyugdíjreform egyik legfontosabb célja az implicit államadósság csökkentése. Ez viszont nem lehetséges úgy, ha közben az explicit államadósság növekszik. Egyszerübben fogalmazva, az lett volna a hosszú távra előre gondolkodó viselkedés, ha

\footnotetext{
${ }^{3}$ Ezen a ponton nem kerülhető meg, hogy a jelen cikk szerzője elmondja, hogy 1998. január 1-től - László Csaba kollégájaként, ugyancsak helyettes államtitkári rangban - felelős volt a már korábban kidolgozott magánnyugdíjpénztári rendszer bevezetéséért. Bár sok döntést a fejünk felett hoztak, végső soron László Csabával a felelősségünk közös mindazért, ami 1997/98 fordulóján történt.
} 
a folyó költségvetés egyenlegét a reform, azaz a II. pillér bevezetése már az indulás évében sem érintette volna, vagyis a kieső járulékbevételt adónöveléssel és/vagy más területeket érintő, azonos mértékű kiadáscsökkentéssel ellensúlyozzuk. A mából visszatekintve ez érthetö, de rossz kompromisszum volt. Ám a II. pillér felszámolása, ha számításra alapozott döntés volt - mint már utaltam rá -, nem az éves deficitnövelö tétel, hanem a kötelező rendszerbeli felhalmozott magánnyugdíjvagyon, a 3000 milliárd forint megszerzése miatt történt. A kormány nem a 2011es év GDP-jének 1,4 százalékát, hanem a 10 százalékát, a felhalmozott magánnyugdíjvagyont akarta visszaállamosítani.

Van ennek a történetnek azonban egy még általánosabb tanulsága is. A szocialista Magyarország kormánya egyszerüen meghamisította a makrostatisztikát, a költségvetés, a fizetési mérleg és a külföldi adósság számait. Erre 1989-ben - még a rendszerváltás előtt - fény derült. Azóta ilyesmi nem történt, de a rendszerváltás utáni kormányok sem tudtak ellenállni annak a kísértésnek, hogy kozmetikázzák a makroadatokat, és/vagy kivételes elbánást, időleges felmentést kérjenek az EU-tól és az IMF-től az éppen akkor érvényes elszámolási szabályok szigorú betartása alól. László Csabának igaza van: „A költségvetési szabályok bevezetése egyúttal a kísértést is megteremti a szabályok megkerülésére." (868. o.) A felelős kormányzás első számú princípiuma azonban éppen az, hogy ellen kell állni a kreatív könyvelés, a kozmetikázás (angolul: window dressing) kísértésének, és az sem helyes, ha egy kormány a statisztikai elszámolások elkészítése során próbál lobbizással pozíciót javítani. A kötelező magánnyugdijpénztári rendszer ügyében a mindenkori magyar kormányok végeredményben mindig meg is feleltek az aktuális szabályoknak. Âm a kedvezőbb elszámolás érdekében kifejtett, „sikeres” lobbitevékenység 2005 és 2010 között következetlen szabályokhoz vezetett, amelyek időlegesen rossz irányba befolyásolták a magyar döntéshozókat. S amikor az Európai Unió illetékesei ezeket az ideiglenes szabályokat megszüntették, nagyon nagy alkalmazkodási többletteher keletkezett.

\section{Hivatkozás}

NÉMETH GYöRGY [2009]: A nyugdíjreformról. Közgazdasági Szemle, 53. évf. 3. sz. 239-269. o.

Mihályi Péter

Mihályi Péter egyetemi tanár, Budapesti Corvinus Egyetem Makroökonómia Tanszék. 